\title{
REPRODUCTIVE PERFORMANCE OF VEMBUR SHEEP IN ITS HOME TRACT
}

\author{
R. SELVAKKUMAR* ${ }^{*}$ T. SIVAKUMAR ${ }^{1}$, S. MEENAKSHI SUNDARAM ${ }^{2}$ \\ K. THILAK PON JAWAHAR ${ }^{3}$ AND T. THAMIL VANAN ${ }^{4}$ \\ Pulikkulam Cattle Research Station \\ Manamadurai-630 606 (TANUVAS) \\ Tamil Nadu, India
}

\begin{abstract}
Vembur sheep is a mutton type sheep breed distributed in Tamil Nadu state, India and the animals are maintained in a traditional way. A study was conducted to record the reproductive performance of Vembur sheep under extensive and semi intensive system of management. Age at maturity, age at first lambing and lambing interval were $509.41 \pm 9.83,659.41 \pm 9.83$ and $285.96 \pm 5.38$ days for the animals in semi intensive system, and 525.81 \pm 7.11, 675.81 \pm 7.11 and $292.90 \pm 3.08$ days for the animals in extensive system of management. Number of lambs produced in its life time was $6.00 \pm 0.13$ and $7.02 \pm 0.76$, respectively for the animals in semi intensive and extensive system of management. Twining percentage were 1.02 and 1.24 , respectively for the two systems of management.
\end{abstract}

Key words: Management systems, Reproductive performance, Sheep, Vembur

Vembur sheep is one among the hairy medium-sized mutton type sheep breed distributed in Thoothukudi, Virudhunagar and few parts of Tirunelveli districts in Tamil Nadu, India. Field surveys carried out in the native breeding tract revealed that Vembur sheep breed is being maintained by the farmers in a traditional way. Perusal of literature revealed that the data about reproductive traits are scanty. Hence, a detailed study about the reproductive performance of Vembur sheep was done which may help for further improvement of this breed.

\section{MATERIALS AND METHODS}

The reproductive performance of Vembur sheep was carried out in its breeding tract (Thoothukudi and Virudhunagar districts in Tamil Nadu). They were maintained in extensive rearing system in the villages as well as at the Vembur sheep unit at

\footnotetext{
*Corresponding Author

${ }^{1}$ Veterinary College and Research Institute, Orathanadu (TANUVAS), Tamil Nadu, India

${ }^{2}$ Livestock Farm Complex, Madhavaram, Chennai-600 051 (TANUVAS), Tamil Nadu, India

${ }^{3}$ Department of Animal Genetics and Breeding, Madras Veterinary College, Chennai- 600007

(TANUVAS), Tamil Nadu, India

${ }^{4}$ Department of Livestock Production Management, Madras Veterinary College, Chennai- 600

007(TANUVAS), Tamil Nadu, India
} 
Livestock Farm Complex (LFC), Veterinary Collage \& Research Institute (VCRI), Thirunelveli, in semi intensive way.

The data available in the LFC, VCRI, Thirunelveli from 2000 to 2015 were used to analyze the reproductive performance of Vembur sheep in semi intensive system of rearing. In field condition (extensive system), the study on Vembur sheep was conducted in 32 villages selected randomly in Thoothukudi and Virudhunagar districts of Tamil Nadu State, India. The data were collected from 113 randomly selected farmer flocks from the selected villages.

In field condition (extensive system), the age at maturity and age at first lambing for females were collected to the nearest month. Lambing percentage was calculated based on number of ewes available in the flock. In addition, details on lifetime number of lambings, twinning percentage, breeding and lambing seasons were also recorded by direct interview with the farmers. Abnormality or difficulties in lambing, if any, were also noted. In farm animals, all the above parameters were considered form the records maintained at LFC.

\section{RESULTS}

Reproductive performance of Vembur sheep reared under two different systems of management is given in Table 1.

Table 1. Mean $( \pm \mathrm{SE})$ of reproductive parameters of Vembur ewes at different systems of rearing

\begin{tabular}{lcccccc}
\hline & $\begin{array}{c}\text { Age at } \\
\text { maturity } \\
\text { (Days) }\end{array}$ & $\begin{array}{c}\text { Age at first } \\
\text { lambing } \\
\text { (Days) }\end{array}$ & $\begin{array}{c}\text { Lambing } \\
\text { interval } \\
\text { (Days) }\end{array}$ & $\begin{array}{c}\text { Lambing } \\
\text { percentage }\end{array}$ & $\begin{array}{c}\text { Life time } \\
\text { lambing }\end{array}$ & $\begin{array}{c}\text { Twining } \\
\text { percentage }\end{array}$ \\
\hline $\begin{array}{l}\text { Semi } \\
\text { intensive } \\
\text { system }\end{array}$ & $\begin{array}{c}509.41 \pm 9.83 \\
(59)\end{array}$ & $\begin{array}{c}659.41 \pm 9.83 \\
(59)\end{array}$ & $\begin{array}{c}285.96 \pm 5.38 \\
(71)\end{array}$ & $75.40 \pm 2.31$ & $6.00 \pm 0.133$ & 1.02 \\
Extensive & $525.81 \pm 7.11$ & $675.81 \pm 7.11$ & $292.90 \pm 3.54$ & $71.61 \pm 1.77$ & $7.02 \pm 0.76$ & 1.24 \\
system & $(93)$ & $(93)$ & $(93)$ & & $(93)$ & \\
T value & 1.381 & 1.38 & 1.20 & 1.13 & 1.13 & - \\
Significance & $\mathrm{NS}$ & $\mathrm{NS}$ & $\mathrm{NS}$ & $\mathrm{NS}$ & $\mathrm{NS}$ & - \\
Overall & $519.44 \pm 5.80$ & $669.44 \pm 5.804$ & $289.90 \pm 3.08$ & $72.56 \pm 1.46$ & $6.51 \pm 0.45$ & 1.13 \\
& $(152)$ & $(152)$ & $(164)$ & & $(159)$ & \\
\hline
\end{tabular}

NS - Not significant, figures in the parenthesis indicate the number of observation 


\section{DISCUSSION}

The major and minor breeding seasons observed in the present study viz. March to May and July to September were in line with the findings of Padmanaban (1994) and Chandran (1998) in the breeding tract of Vembur sheep. In spite of seasonality, lambing was observed throughout the year in Vembur sheep during the study period. Chandran (1998) reported that in Vembur breeding tract, there was two breeding seasons: March to May (major) and July to September (minor). He further stressed that in spite of seasonality, lambing throughout the year was not uncommon.

No significant difference was found between the systems of rearing in the values on reproductive parameters like age at maturity, age at first lambing, lambing interval, lifetime lambing and twining percentage. The numerical difference might be due to the scientific care on feeding and health management in semi intensive system of rearing.

The age at maturity of 519 days recorded for Vembur breed of sheep in the present study was almost similar to the study conducted by Dass et al. (2004) in Marwari sheep. Contrary to the present findings, lower age at maturity was recorded in Ganjam sheep (Mishra et al., 2004), Mecheri sheep (Karunanithi et al., 2004), Sonadi sheep (Tailor et al., 2007) and Edka sheep (Panda et al., 2012) and higher age at maturity in Deccani sheep (Mane et al., 2014).
Age at first lambing in Ganjam sheep (Nayak et al., 2008), Munjal sheep (Poonia, 2008) and Edka sheep (Panda et al., 2012) was lesser than the observations recorded in Vembur sheep in the present study. Similar lambing interval of 275.8, 301.60 and 307.90 days were reported for Sonadi sheep (Tailor et al., 2007), Ganjam (Nayak et al., 2008) and Deccani (Mane et al., 2014).

Lambing percentage of Vembur sheep recorded in the present study was $72.56 \pm 1.46$. Whereas, varying lambing percentages were reported by Acharya (1982) and Chandran (1998) in same Vembur sheep during their respective study.

The overall lifetime lambing of Vembur sheep observed in the present study was in agreement with the findings of Chandran (1998) in Vembur sheep and Raja et al. (2012) in Ramnad White sheep. In semi intensive system of management (Farm animals), periodical policy culling were carried out and the ewes after 6th lambing were removed from the herd and this might be the reason for low lifetime lambing than the extensively reared animals.

The overall twinning percentage in Vembur sheep observed was in agreement with the findings of Chandran (1998) for the same breed of sheep and Kumar (2007) in Mecheri sheep.

In conclusion, there was no significant difference was found between the two systems of management in reproductive 
performance of the Vembur sheep and the numerical difference between these two groups might be due to the scientific management of animals in semi intensive system.

\section{REFERENCES}

Acharya RM, 1982. Sheep and goat breeds of India. In: FAO (UN) (Eds). Animal Production and Health Paper, 30, Food and Agricultural Organization of the United Nations, Rome, pp8,190

Chandran PC, 1998. Characteristics and Performance of Vembur sheep in the habitat. M.V.Sc., thesis submitted to Tamil Nadu Veterinary and Animal Sciences University, Chennai, India

Dass G, Singh VK, Mehta SC and Sharma PR, 2004. Reproductive traits of Marwari sheep in arid Rajasthan. Indian J Small Rum, 10: 88-89

Karunanithi K, Purushotheman MR, Thiruvenkadam AK, Singh G, Sadana DK et al., 2004. Mecheri sheep monograph. TANUVAS, pp80

Kumar S, 2007. Commercial goat farming in India: An emerging Agri-Business opportunity. Agri Eco Res Review, 20:503-520

Mane PM, Pachpute ST and Nimase RG, 2014. Growth and reproductive performance of deccani sheep in an organised farm. Indian J Small Rum, 20 (2): 23-27

Mishra PK, Barik N, Patrn BN, and Nayak S, 2004. Production potentiality of Ganjam

\section{ACKNOWLEDGEMENT}

The authors are grateful to the staffs of LFC, VCRI, Tirunelveli for their involvement in the execution and data collection for this study.

sheep under extensive management. Indian J Small Rum, 9: 31-34

Nayak S, Sahu G and Mohapatra AK, 2008. Study on management practices, phenotypic and reproductive characteristics of Ganjam sheep under range conditions of Orissa, India. SAARC J Agricul, 6 (2): 93-106

Padmanaban NR, 1994. An analysis of sheep farming in Tamil Nadu with particular reference to economics and resource use efficiency. Indian J Anim Sci, 64: 639-642

Panda P, Rao PK and Kumar P, 2012. Performance of Edka sheep of Puri district of Odisha. Indian J Small Rum, 18(2): 188-190

Poonia JS, 2008. Reproductive performance of Munjal sheep. Indian J Small Rum, 14(1): 121-123

Raja KN, Jain A, Singh G, Luv kumar, Tadav KK, et al., 2012. Ramnad White sheepphenotypic and genetic characterization. Indian J Anim Sci, 82(9): 1082-1086

Tailor SP, Gupta L and Nagda RK, 2007. Productive and reproductive performance of sonadi sheep in their native tract. Indian J Small Rum, 13(1): $51-54$

Article received on 23.04.2019 and accepted for publication on 24.05.2019 